DOI 10.14746/ssp.2014.4.1

\title{
Andrzej GAŁGANEK
}

Uniwersytet im. Adama Mickiewicza w Poznaniu

\section{Międzynarodowe życie rzeczy. Wprowadzenie}

$\mathrm{W}$ XX-wiecznym dyskursie filozoficznym i naukowym materialność życia społecznego była marginalizowana, a nawet stygmatyzowana ${ }^{1}$. Tymczasem, jeśli istnieje jakaś jedna historia społeczeństw ludzkich, to jest to historia rosnącej materializacji - coraz więcej zadań przekazuje się czynnikom nie-ludzkim i coraz więcej działań jest zapośredniczanych przez rzeczy (Olsen, 2010, s. 565). Francuski filozof Michel Serres przekonuje, że gdyby istniały tylko kontakty między podmiotami, to nasze relacje i związki społeczne byłyby „mgliste jak chmury”. W istocie bowiem to przedmiot, wyróżnik człowiekowatych stabilizuje nasze relacje (Serres, 1995, s. 87). Równocześnie „w gwałtowności walk, w sieciach wymian, na ołtarzach kultów" rzeczy nie pozostają rzeczami, ale są przekształcane w fetysze i stają się stawkami. W bankach, na rynkach kapitałowych i w centrach handlowych wymiana przekształca rzeczy w towary. Nadawanie rzeczom ceny nadaje również właściwego smaku naszym relacjom. Czym byłoby nasze życie bez tego smaku? - pyta Serres. Czy możemy dzisiaj dotknąć lub spojrzeć na rzecz, która nie jest stawką, fetyszem lub towarem? Próbę usunięcia ceny z rzeczy podjął Diogenes, chcąc dotrzeć do relacji innych niż walka, wymiana czy kult. Poszukiwał jednak rzeczy utraconej (Serres, 1989, s. 69). Związek społeczny byłby rozmyty i niestabilny, gdyby nie był urzeczowiony.

Ilustrując postępujące zacieranie się różnicy między „,kulturą” a ,przyrodą" często przywołuje się zachodzący od początków gatunku ludzkiego proces przenoszenia funkcji spełnianych przez organy ludzkiego ciała na narzędzia. „W trakcie tego procesu od pierwszej chwili przenoszono na sztucznie wytworzone przedmioty zewnętrzne nabytą/odziedziczoną wiedzę i doświadczenie ludzkie [...]. Nowością [tego procesu - przyp. A.G.]

Artykuł jest rozszerzoną wersją tekstu opublikowanego w książce Andrzej Gałganek, Historia stosunków międzynarodowych. Nierówny i połaczony rozwój, Elipsa, Warszawa 2013, s. 627-638. 
jest przenoszenie na przedmioty zewnętrzne funkcji umysłowych; najpierw pamięci, czyli składowania informacji, a obecnie także i jej przerobu; a coraz częściej również i wyboru celu i podejmowania decyzji (jak choćby w przypadku «inteligentnych pocisków»). Zaciera się więc również granica, do niedawna ostro zarysowana, między podmiotem a przedmiotem, człowiekiem a jego wytworami. [...] Wytwory ludzkie nabywają ludzkich cech, zaś ludzie coraz częściej okazują się «przedmiotami» sztucznie wytworzonych «podmiotów» (Bauman, Kubicki, Zeidler-Janiszewska, 2009, s. 133-134).

Rzeczy cyrkulujące poza granicami ich miejsc narodzenia rzadko są tylko „kopiami” swojego kontekstu społecznego, często zaś zmieniają uprzednio nadawane im znaczenia i prowadzą do istotnych zmian w różnych sferach życia społecznego: życiu codziennym, politycznym i ekonomicznym. Przemiana ta dokonuje się w szczególny sposób w stosunkach międzynarodowych, które przekształcają, na przykład, statek w okręt czy pieniądz w walutę. Rzeczy często wracają do źródła swego wytworzenia wraz z nadanym im nowym kontekstem społecznym i wpływają w istotny sposób na to źródło. Michael Taussig nazywa to zdolnością kopii do wpływania na to co jest kopiowane (Taussig, 1993, s. XIII).

Autorzy tekstów składających się na ten zbiór wykorzystują rozwiązanie jednej z tradycyjnych kwestii związanych z uprawianiem nauk społecznych przez teorię aktora-sieci (Actor-Network Theory, dalej ANT) do lepszego rozumienia stosunków międzynarodowych. Kwestią tą - stanowiącą poważne źródło niepewności w naukach społecznych - jest sprawczość rzeczy.

ANT przyciagga uwagę badaczy stosunków międzynarodowych, obiecując ich uwolnienie od dualizmów takich jak agent czy struktura; materializm czy idealizm oraz natura czy społeczeństwo. I chociaż trudno w interesującym nas zakresie jednoznacznie odpowiedzieć na pytanie czy ANT jest czymś więcej aniżeli tylko „nowym materialistycznym” argumentem na rzecz traktowania rzeczy poważnie, uznaliśmy, że zawarte w niej idee rozszerzają naszą teoretyczną i metodologiczną wyobraźnię rozumienia międzynarodowości.

W 1910 roku antropolog W. H. R. Rivers zauważył, że poszukując reguł dziedziczenia możemy porównać ich idealną formę z rzeczywistym 
ruchem poszczególnych rzeczy poprzez genealogiczny diagram ukazujący jak przechodzą one z rąk do rąk. Rivers zaproponował zatem rodzaj „biografii rzeczy” w kategoriach własności. Tworząc taką biografię rzeczy możemy zadawać pytania podobne do tych, które zadajemy w stosunku do ludzi. Jakie są biograficzne możliwości rzeczy zawarte w jej „statusie” związanym z danym okresem i kulturą oraz jak te możliwości się zrealizowały? Skąd dana rzecz przybyła i kto ją stworzył? Jaka była jej kariera? Jak użyteczność danej rzeczy zmieniała się z jej wiekiem i co stanie się z nią kiedy osiągnie kres swej użyteczności? (Kopytoff, 1986, s. 66). Idea, że rzeczy mają „społeczną biografię” okazała się jednym $\mathrm{z}$ najbardziej użytecznych modeli $\mathrm{w}$ badaniach kultury materialnej w XX w. W „modelu biograficznym” rzeczy nie można rozumieć w kategoriach pojedynczej, niezmiennej tożsamości, ale raczej należy ukazać następowanie po sobie przypisywanych im znaczeń w ich ruchu przez czas i przestrzeń.

Teza o hybrydycznej naturze ludzi i przedmiotów w ANT Bruno Latoura ma swoją genealogię w antropologii. Strukturalizm Mary Douglas, Claude'a Lévi-Straussa i innych, rekonfigurował kulturę materialną jako tekst, podczas gdy poststrukturalizm, utrzymując tekstualną metaforę, wskazywał na semiotyczne konstruowanie i wielość znaczeń nadawanych rzeczom przez różnych obserwatorów i użytkowników. Warto także przypomnieć charakteryzujący neomarksistów zwrot ku procesom wymiany i komodyfikacji zaproponowany przez Arjuna Appadurai, Igora Kopytoffa $\mathrm{i}$ innych w poł. lat 80 . XX wieku. Cyrkulacja i reklasyfikacja przedmiotów (obiektów) poprzez rynki i różne rodzaje powierzchni wystawowych, a także kontestacja sposobów w jakie obiekty były rekontekstualizowane w muzeach była badana przez Sally Price, Jamesa Clifforda, Freda Meyersa, Chrisa Gosdena i Chantal Knowles. Daniel Miller, czerpiąc inspiracje od Hegla, wskazywał na procesy samokreacji poprzez konsumpcję rzeczy. Teoretycy antropologii sztuki akcentowali znaczenie formalnej analizy rzeczy w celu zrozumienia jak ich specyficzne jakości działają w interpersonalnej i międzykulturowej komunikacji (Edwards, Gosden, Philips, 2006, s. 9).

Bruno Latour definiuje ANT przede wszystkim jako „infra-język”. W przeciwieństwie do „meta-języka” innych teorii, pojęcia konstruowane w ramach ANT nie chcą narzucać żadnego porządku na badanych aktorów lub zakładać, że postępują oni według jakiejś odrębnej logiki. Dbając o ontologiczną oszczędność ANT unika a priori założeń rozstrzygających czy zjawisko jest macro czy micro, uniwersalne czy partykularne, natural- 
ne czy społeczne. Badacze ANT ukazująjak tego rodzaju założenia (pojęcia) zmieniają się często $\mathrm{w}$ przedmiot badania, a granice między naturą i społeczeństwem są upolityczniane/polityzowane. Odrzucanie tego typu dualizmów oznacza opowiadanie się za epistemologiczną, a nade wszystko ontologiczną wielością. Istnieje więcej niż jedna ontologia i ontologie te krzyżują się ze sobą i konfliktują. Stąd dyspozycja, aby skupiać się na działaniach, których skutkiem jest wytwarzanie światów, które badamy (Bueger, 2013, s. 339-340).

Punktem wyjścia ANT jest teza o podobnych do sieci powiązaniach między natura, przedmiotami i istotami ludzkimi. Natura, przedmioty i społeczeństwo (zbiorowość) tworzą hybrydowe sieci, które utrzymują i stabilizują, ale też destabilizują społeczne powiązania. Społeczeństwa odróżniają się od siebie przede wszystkim splataniem odmiennych elementów w społeczną strukturę. Równocześnie „społeczny” nie oznacza żadnego pojedynczego ogniwa w tym łańcuchu, ani nawet samego łańcucha, ale sam proces „łańcuchowania” (chaining) (Latour, 2007, s. 4). Proces ten obejmuje ludzi i nie-ludzi oraz technologię przyczyniającą się do tworzenia takich heterogenicznych sieci. Technologii nie sprowadza się do zwykłych materialnych stosunków i nie ocenia jako narzędzia gwarantującego postęp i pokój. Jest ona raczej typem technicznego powiązania rodzącym złożone heterogeniczne zagrożenia. Aktorzy do pewnego stopnia są sieciami i nie mogą bez nich działać. Są sieciami składającymi się z heterogenicznych stosunków lub skutków, które są wytwarzane przez takie sieci. Są aglomeratami dóbr materialnych, faktów, wiedzy, wizji, nabytej władzy i znaczenia. W ANT jednostka ludzka (podmiot sprawczy) i kontekst społeczny (struktura) przenosi się na dalszy plan. Na planie pierwszym znajdują się ,mediatorzy”: „[a]ni podmioty, ani osoby, jednostki czy uczestnicy, ani nawet społeczeństwo czy też któreś z jego wcieleń, ale rzeczy, quasi-przedmioty oraz załączniki [możliwości sprawiania, że ktoś coś czyni - przyp. A.G.] stanowią rzeczywiste centrum świata społecznego" (Latour, 2010a, s. 346).

Według Bruno Latoura „niewzruszona” obecność nierówności, asymetrii i hierarchii w świecie społecznym dowodzi, że jeśli są one wytwarzane oznacza to pojawienie się na scenie innych typów aktorów niż aktorzy społeczni. Również stosunki międzynarodowe, podobnie jak władza czy społeczeństwo są wynikiem końcowym pewnego procesu: musiały zostać „wytworzone, wypracowane i uporządkowane”. Jeśli pojawiają się w nich nierówności, asymetrie i hierarchie, to skąd się one wzięły i z czego zostały wytworzone? (Latour, 2010a, s. 90). 
Jeśli analizujemy podstawowe kompetencje społeczne - pisze Latour - powiązania jakie one tworzą zawsze pozostają zbyt słabe, aby zachować ważność tego, co uważamy za społeczne. Na przykład, gdyby relacja władzy korzystała jedynie z kompetencji społecznych byłaby ograniczona do krótkotrwałych i nietrwałych interakcji. Tymczasem władza jest trwała właśnie dlatego, że nie jest ona utworzona z powiązań społecznych. Ponieważ w istocie trudno jest zachować asymetrię i wprowadzić w życie społeczne nierówności, należy nieustannie pracować nad zamienianiem słabych i ciagle rozpadających się powiązań na innego typu związki. Mówiąc o trwałości powiązań społecznych, socjologowie zwykle przekonują, że „społeczeństwo”, „norma społeczna”, ,prawa społeczne”, ,zwyczaje”, „kultura” lub „reguły” mają moc wywierania presji tłumaczącej nierówności światów, w których żyjemy. Według Latoura nie tłumaczy to jednak skąd pochodzi siła, która wzmacnia słabe powiązania kompetencji społecznych. Kiedy socjologowie powołują się na trwałość jakichś agregatów społecznych, zawsze, celowo lub nieświadomie, nadają słabym powiązaniom społecznym duży ciężar w swej istocie pochodzący z wielu innych niespołecznych rzeczy. „A to zawsze są rzeczy - $\mathrm{i}$ teraz traktuję to ostatnie słowo literalnie - które w praktyce nadają swoją «stalową» jakość nieszczęsnemu «społeczeństwu»" (Latour, 2010b, s. 532).

Latour przywołuje wnioski Shirley Strum z badań nad społecznościami pawianów, z których wynika, że wśród pawianich samców nie ma hierarchii dominacji; że pawiany posiadają strategie społeczne; że w ich życiu społecznym finezja góruje nad siłą, a kompetencje społeczne i społeczna wzajemność mają pierwszeństwo przed agresją. Aby wytworzyć taki świat społeczny pawiany muszą ciężko pracować: wymieniać się przysługami, zapewniać sobie wzajemną ochronę, troszczyć się o swoje podstawowe potrzeby niezbędne do przetrwania, być dla siebie „miłe”. Pawiany wydają się „miłe” również dlatego, że w przeciwieństwie do ludzi żaden członek stada nie posiadł zdolności do kontrolowania podstawowych zasobów. „Gdyby socjologowie posiadali przywilej przyjrzenia się bliżej pawianom, kiedy reperują one swoją nieustannie rozpadającą się «strukturę społeczną», zaobserwowaliby - pisze B. Latour - jak ogromne koszty trzeba ponieść, podejmując zadanie, na przykład, podtrzymania dominacji społecznej bez obecności żadnej rzeczy, jedynie za pomocą kompetencji społecznych" (Latour, 2010a, s. 98-99). Inaczej mówiąc, kiedy wierzy się, że grupa społeczna może istnieć, opierając się na „siłach społecznych”, to przedmioty znikają z pola widzenia, a magiczna siła społeczeństwa wystarcza do zachowania każdej rzeczy, bez pomocy jakichkolwiek rzeczy. 
Początkowo - argumentuje Latour - przywrócenie rzeczy do normalnego przebiegu działania wydaje się zabiegiem oczywistym (czajniki „gotują" wodę, noże „kroją” mięso, zamki „zamykają” drzwi, mydło „zmywa” brud, ceny „pomagają” ludziom liczyć itd.). Jednak w istocie to każda rzecz, która zmienia sytuację społeczną, wprowadzając jakąś różnicę jest aktorem lub, jeśli nie posiada jeszcze figuracji - aktantem (actant), czyli uczestnikiem przebiegu działania czekającym na nadanie mu figuracji (Latour, 2010a, s. 100). Nie oznacza to, że przedmioty „robią” pewne rzeczy „zamiast” podmiotów. Jednak z punktu widzenia analizy działania społecznego oznacza to, że pojawiają się w nim elementy, które Latour nazywa czynnikami pozaludzkimi. Przedmioty (rzeczy) stają się w tej perspektywie ,pełnoprawnymi aktorami”. Tim Dant pisze, że zwykle nie myślimy o stosunkach między ludźmi i przedmiotami jako ,interakcji”, ponieważ istoty ludzkie charakteryzuje intencja, podczas gdy rzeczy nie (Dant, 1999, s. 121). Jednak wartości przypisywane rzeczom wpływają na ludzi w taki sposób, że zasadnie możemy pytać: „czego rzeczy chcą”?

Trudność w dostrzeżeniu roli rzeczy wynika z niewspótmierności ich sposobów działania z tradycyjnie pojmowanymi powiązaniami społecznymi. Jednak „,[...] socjologowie tego, co społeczne źle zrozumieli naturę tej niewspółmierności. Ich wniosek brzmiał, że skoro są one niewspółmierne, powinno się oddzielić przedmioty od właściwych powiązań społecznych, nie rozumiejąc, że powinni dojść do wniosku zupełnie przeciwnego: właśnie dlatego, że są niewspółmierne, zostały one w ogóle przyprowadzone! Jeśli byłyby tak słabe jak kompetencje społeczne, dla których muszą stanowić oparcie, gdyby były tworzone z materii tej samej jakości, jaki byłby z nich zysk? Pozostalibyśmy pawianami, tak jak pawianami byliśmy" (Latour, 2010a, s. 104-105).

Trawestując opinię Latoura można powiedzieć, że w nauce o stosunkach międzynarodowych (dalej NSM), „[...] o przedmiotach nigdzie się nie mówi, ale wszędzie da się je odczuć. Istnieją one, rzecz jasna, ale nie poddaje się ich namysłowi [...]. Jak pokorni służący istnieją one na marginesie tego, co społeczne [międzynarodowe - przyp. A.G.], wykonują większość pracy, ale nigdy się ich tak nie przedstawia. [...] Jednak, jak tylko klątwa zostanie z nich zdjęta, zaczynają one podrygiwać, rozciagać się, mamrotać. Zaczynają mrowić się we wszystkie kierunki, potrząsać innymi ludzkimi aktorami [...]" (Latour, 2010a, s. 104). W istocie, pozornie słuszne rozróżnienie pomiędzy materialnym a społecznym zaciemnia każde badanie zbiorowego działania. W ANT twierdzi się, że po prostu nie powinniśmy traktować jako oczywistości, że kwestia powiązań między 
heterogenicznymi aktorami jest zamknięta. To, co zwykle rozumie się przez „to, co społeczne” wiąże się z ponownym splataniem nowych typów aktorów. „W ANT uważa się, że jeśli chcemy być nieco bardziej realistyczni w kwestii powiązań społecznych niż «rozsądni» socjologowie, musimy zaakceptować, że na ciagłość jakiegokolwiek przebiegu działania rzadko składają się powiązania ludzi-z-ludźmi [...] czy powiązania przedmiotów-z-przedmiotami, ale [że] prawdopodobnie zygzakowate przejścia od jednych do drugich" (Latour, 2010a, s. 106). Latour z mocą podkreśla, że ANT nie polega na ustanawianiu jakieś absurdalnej ,symetrii pomiędzy czynnikami ludzkimi i pozaludzkimi”. Symetryczność oznacza nie narzucanie z góry nieuzasadnionej asymetrii między intencjonalnym ludzkim działaniem a materialnym światem relacji przyczynowych. Równocześnie przedmioty są $\mathrm{w}$ stanie wiązać się między sobą i z powiązaniami społecznymi tylko chwilowo. Ponieważ większość prac badaczy identyfikujących się z ANT poświęcona została analizie takich przypadków warto je w tym miejscu przywołać jako metodę postępowania badawczego.

Po pierwsze, badać należy innowacje w inżynieryjnych wydziałach projektowych, warsztatach, laboratoriach, działaniach marketingowych i domach użytkowników. „W tych miejscach przedmioty wyraźnie wioda wielorakie i złożone życie poprzez spotkania, plany, szkice, regulacje i próby. Tutaj wydają się w pełni pomieszane z innymi bardziej tradycyjnymi podmiotami społecznymi" (Latour, 2010a, s. 113-114). W takich miejscach przedmioty utrzymują się dłużej jako widoczni mediatorzy, zanim staną się niewidocznymi, aspołecznymi zapośredniczeniami. Po drugie, powiązań tych należy poszukiwać w sytuacjach nowości, kiedy egzotyczne, archaiczne lub tajemnicze przedmioty burzą zwykły przebieg działania. Po trzecie, okazji do badania tych powiązań dostarczają sytuacje nadzwyczajne (wypadki, awarie, strajki, konflikty). Po czwarte, nawet wtedy gdy przedmioty znikają w tle możliwe jest ich przywrócenie za pomocą archiwów, dokumentów, wspomnień, zbiorów muzealnych. „Nawet najskromniejsze i najstarsze kamienne narzędzia z Wąwozu Olduvai zostały przez paleontologów przekształcone w mediatorów, którzy zapoczątkowali ewolucję «człowieka nowoczesnego»" (Latour, 2010a, s. 115-116). Po piąte wreszcie, kiedy wszystko inne zawodzi można odwołać się do fikcji (kontrfaktycznej historii czy eksperymentu myślowego).

Wyjaśnienia oferowane przez NSM często są naznaczone ryzykiem ukrycia tego, co powinny wyjaśniać, ponieważ pozostają one zbyt często „bez przedmiotu”. Stosunkom międzynarodowym nieodłącznie towarzyszą przedmioty. Zarówno kooperację, jak i podbój, dominację i pod- 
porządkowanie, zmianę i stabilność można objaśniać poprzez wielość przedmiotów odgrywających w nich centralną rolę. Kiedy jakiś stan rzeczy jest podzielony na składnik materialny, do którego dodano jako aneks składnik społeczny - a jest tak w istocie we wszystkich konceptualizacjach stosunków międzynarodowych z konstruktywizmem włącznie - jest to podział sztuczny i nieuzasadniony żadnym wymogiem empirycznym. „Oznacza on zwyczajnie, że większość danych zniknęła, a zbiorowy przebieg działania nie został prześledzony" (Latour, 2010a, s. 118).

Na przykład, „za” eksperymentami lorda Kelvina z telegrafem kryje się nie tylko Imperium Brytyjskie, ale to eksperymenty te dały mu zasięg, szybszy czas reakcji i trwałość, której by nie miało bez kabli rozłożonych na oceanicznym dnie. W 1900 r. brytyjska Wschodnia Kompania Telegraficzna (Eastern Telegraph Company) była operatorem ok. 72 tys. mil podmorskich kabli, co stanowiło czterokrotność w porównaniu z najbliższym jej konkurentem. Reakcją na „kablowanie” świata była mieszanina kooperacji i oporu, a przedsięwzięcie to nie było realizowane w oparciu o demokratyczne zasady. Modernizujące swoje państwa elity Persji, Chin czy Brazylii podejmowały, zazwyczaj nieskuteczne, próby kanalizowania lub powstrzymania tego procesu. W latach 80 . XIX wieku brytyjska Wschodnia Kompania Telegraficzna pomogła Wielkiej Brytanii podporządkować sobie Egipt poprzez czasowe odłączenie Aleksandrii od globalnej sieci komunikacyjnej. „Odkrycie”, że kablowe sieci komunikacyjne dostarczają wielkiej strategicznej przewagi wiązało się przede wszystkim z doświadczeniami I wojny światowej i implikacjami płynącymi z dominacji Wielkiej Brytanii w tym względzie nie tylko nad Niemcami, ale także nad Stanami Zjednoczonymi. Wielka Brytania przecięła i przekierowała niemieckie kable podmorskie; patriotyczne wiadomości przygotowywane i rozsyłane przez Reutersa były zgodne z brytyjskim interesem; tajne telegramy przechodzące przez brytyjskie sieci były przejmowane i dekodowane. Dominacja w dziedzinie podmorskich kabli telegraficznych przekładała się nie tylko na przewagę w strategii militarnej, ale także korzyści w sferze wiadomości, dyplomacji i działalności ekonomicznej. Wraz z tym odkryciem sfera komunikacji międzynarodowej stała się teatrem walki. W szczególności rywalizacja ta wiązała się z wyłonieniem się Stanów Zjednoczonych jako najpoważniejszego rywala dla pozycji Wielkiej Brytanii. Wraz z procesem transnacjonalizacji amerykańskiego kapitału i amerykańskich sił zbrojnych (Filipiny, Hawaje, Guam), a w szczególności po I wojnie światowej, amerykańscy liderzy polityczni i korporacyjni podjęli decyzję o budowie niezależnej eksterytorialnej sieci ze 
Stanami Zjednoczonymi w jej centrum. Cel ten udało się zrealizować w pełni po II wojnie światowej. Stany Zjednoczone stały się państwem, które ustanowiło swoją dominację nad sieciami komunikacyjnymi. Działania te ułatwiała amerykańska dominacja technologiczna w nowych środkach komunikacji takich jak radio (fale krótkie), podmorskie kable telefoniczne, komunikacja satelitarna i światłowodowa. Poprzez system Intelsat (International Telecommunications Satellite) Stany Zjednoczone nie tylko blokowały stworzenie europejskiego systemu satelitarnego, ale także zapewniły kapitałowi amerykańskiemu dominującą pozycję konkurencyjną. Za klamrę zamykającą te działania można uznać współczesną dominację amerykańską w ekonomii politycznej internetu (Microsoft, Intel, Apple, Facebook, Twitter, eBay, Amazon, Wikipedia, Google). Eksterytorialność internetu nie mogła zostać zbudowana wyłącznie przez unilateralne działania Stanów Zjednoczonych i międzynarodowa kooperacja była niezbędna do jego rozwoju. Presje płynące ze strony internetu jako sposobu komunikowania się powodowały jednak, że wiele państw rezygnowało z niektórych atrybutów wiązanych z suwerennością w celu umożliwienia jego działania jako systemu supranarodowego. Nie były to wyłącznie zewnętrzne presje polityczne, ale również wynikające z korzyści jakie oferowała nowa infrastruktura komunikacyjna transnarodowemu kapitałowi (Schiller, 2011, s. 97).

$$
* * *
$$

Ludzie angażują się w świat poprzez materialność. Niekiedy określają samych siebie poprzez tworzenie swoich społecznych tożsamości za pośrednictwem manipulacji rzeczami. Manipulują rzeczami w związku z własnymi potrzebami i interesami związanymi z ich stosunkami społecznymi. Rzeczy przyczyniają się do tworzenia złożonych interakcji między ludźmi. Pojęcie praktycznego działania lub praxis wskazuje na istnienie stałej interakcji między ludźmi i ich światem materialnym. Badanie tej materialności stosunków społecznych w ich wymiarze międzynarodowym pozwala w inny sposób spojrzeć na stosunki międzynarodowe i ich historię.

Materialna kultura jest komunikatorem różnych informacji i może symbolizować status, bogactwo czy grupową tożsamość. Poprzez materialną kulturę ludzie konstruują znaczącą część swojego świata, a także utrzymują interakcje z innymi w społeczeństwie. Materialna kultura przyczynia się do sytuowania ludzi w czasie i przestrzeni, wiążąc ich z rzecza- 
mi. Dobra prestiżowe, zwane także „dobrami elitarnymi” lub „dobrami statusu", ukazują bogactwo, sukces i siłę. Ich celem jest rozwiązywanie problemu społecznego lub realizacja społecznego zadania polegającego na przyciagnięciu pożądanego partnera, sojusznika lub związanie członków grupy społecznej poprzez manifestację sukcesu. Dobrami prestiżowymi są cenne surowce lub wytworzone przedmioty wykorzystywane do ustanawiania i utrzymywania stosunków społecznych i politycznych. Zwykle stanowią je obiekty wytworzone z importowanych surowców lub materiałów o ograniczonej dystrybucji, wymagające znacznego nakładu pracy i zastosowania złożonych technologii (Trubitt, 2003, s. 247). W odróżnieniu od dóbr codziennego użytku dobra prestiżowe z powodu ich dużej wartości są wymieniane na długie dystanse poprzez sieci ustanawiane i kontrolowane przez elity. Analiza produkcji i wymiany oraz kontekstów społecznych związanych z prestiżowymi dobrami stanowi zatem ważne źródło dla zrozumienia „makroregionalnych” stosunków. Analizy ukazują zwykle kontrolę nad tymi dobrami jako źródło władzy politycznej. Kontrola surowców, produkcji i dystrybucji dóbr prestiżowych jest postrzegana jako kluczowa z punktu widzenia utrzymywania hierarchicznych systemów społecznych.

Pojęcie „krążenia kultur” rozwijane początkowo przez geografów podkreślało rozmaitość praktyk i systemów wiedzy funkcjonujących między producentami, kupcami i konsumentami poszczególnych dóbr. Podejście sugerowane tutaj koncentruje się raczej na pojęciach segmentacji i kontestacji: rzeczy nabierają różnych znaczeń dla różnych ludzi w różnych miejscach i czasach. Robert Batchelor, porównując praktyki związane z porcelaną w Europie północno-zachodniej oraz Azji w XVII i XVIII w. podkreśla ich związek z różnymi reżimami produkcji i komunikacji. Praktyki związane z porcelaną wzajemnie konstytuowały się. Porcelana dysponowała twórczą moca, która była kształtowana przez odmienne regionalne sieci produkcji i zdobienia: typograficzny reżim świata atlantyckiego ogniskujący się wokół Londynu i Amsterdamu, kaligraficzny reżim Azji południowo-wschodniej i dawnych islamskich sieci handlowych oraz ksylograficzną sieć przybrzeżnych Chin. We wszystkich tych regionach porcelana cyrkulowała w znacznych ilościach (Batchelor, 2006, s. 95-121). Jednak to co najbardziej interesujące, to nie historia zasięgu tego artykułu i dane o liczbie jego konsumentów, ale raczej różne rodzaje reprezentacji, systemów produkcji, sposobów interpretacji, jakich doświadczyła w każdym $\mathrm{z}$ tych regionów. $Z$ rzeczami bowiem nieuchronnie wiążą się idee i praktyki. Nierówny i połączony rozwój społeczeństw prowadzi do spot- 
kań rzeczy i ludzi. Otwiera przestrzeń do ich transferu i udomowienia lub zamyka ją prowadząc do odrzucenia i zniszczenia. Powoduje to, że społeczeństwa odróżniają się od siebie splataniem odmiennych rzeczy w społeczną strukturę.

Ilustracji skutków tego splatania dostarcza kontakt między mieszkańcami Ameryki i Europejczykami. Efekt spotkania między społecznościami znajdującymi się na różnych poziomach rozwoju sił produkcyjnych i dysponujących różną siłą zniszczenia ilustruje dramatycznie inwazja Spaniardów na zachodnią hemisferę. Większa siła niszcząca materialnego wyposażenia skłania do terroru i niszczenia antagonistów. Przekroczenie przez zachodnich Europejczyków Atlantyku oznaczało dla Indian przejście od epoki kamiennej do epoki żelaznej, od organizacji plemiennej opartej na praktykach wspólnotowych do społeczeństwa zakorzenionego we własności prywatnej, produkcji na wymianę, rodzinie, państwie itd. Niewiele wydarzeń w historii było bardziej dramatycznych i pouczających od konfrontacji i konfliktu między Indianami i białymi. W okresie kolonialnym w Nowym Świecie można było odnaleźć prawie każdy rodzaj stosunku społecznego znany ludzkości: od „dzikości” do spółki akcyjnej. Najwyższa forma kapitalistycznej organizacji, spółka akcyjna, weszła w kontakt z Indianami żyjącymi w strukturach plemiennych. Indiańskie plemiona zostały włączone w światowy rynek przede wszystkim poprzez handel futrami. Jednak przekonanie, że amerykańskie kolonie powtarzały sekwencję stadiów przez które przechodziły rozwinięte społeczeństwa jest błędne. Najbardziej znaczącą odrębnością w ewolucji brytyjskich kolonii w Ameryce jest fakt, że wszystkie organizacyjne formy i siły przynależące do wcześniejszych stadiów rozwoju społecznego, od „dzikości” do feudalizmu, zostały włączone, były warunkowane, a w przypadku niewolnictwa, nawet produkowane „na nowo” przez rozszerzający się system kapitalistyczny.

Dla Indian zdobycie i wykorzystywanie rytualnie naznaczonych przedmiotów było żywotne z punktu widzenia ich pomyślności i płodności świata naturalnego. Poprzez proces „transsubstancjacji” wartości zawarte w lokalnych przedmiotach zostały przez Europejczyków przekształcone w wartość handlową. Początkowo Europejczycy byli asymilowani w sieć lokalnych stosunków poprzez znaczenie rzeczy, jakie przynosili ze sobą. Materialność była podstawą dla szczególnej formy socjalności. Celem Francuzów handlujących futrami w rejonie Wielkich Jezior był zysk, a sukces materialny był mierzony kategoriami ilościowymi. W procesie translacji charakterystycznym dla wszystkich kolonialnych kultur euro- 
pejskie formy wartościowania rzeczy zaczęły wypierać formy indogeniczne. Rozwijający się handel futrami i wprowadzenie pieniądza jako miernika wartości wywołało rewolucyjne zmiany prowadzące do rozbicia życia plemiennego, dominacji interesów plemiennych nad wspólnotowymi oraz wzrost konfliktów między plemionami (Novack, 1972, s. 18-19, 80-81, 94-95).

Innego przykładu splatania rzeczy dostarczają relacje brytyjsko-indyjskie. W XIX w. definiującymi autorytatywnie wartość i znaczenie przedmiotów wytworzonych w Indiach byli Brytyjczycy. Stworzyli oni system klasyfikacji określający co jest wartościowe, co powinno zostać zachowane jako pomniki przeszłości, co powinno zostać umieszczone w muzeach, co może zostać kupione i sprzedane, co może zostać zabrane z Indii jako pamiątka relacji z Hindusami. Do pocz. XX wieku Hindusi byli jedynie obserwatorami dyskusji i polemik ustanawiających znaczenie i wartość dla Europejczyków. Od ustanowienia bezpośrednich stosunków handlowych między Wielką Brytanią i Indiami na pocz. XVII wieku, Indie były uważane za źródło towarów, których sprzedaż w Europie i Azji powinna przynosić zyski właścicielom i urzędnikom Kompanii Wschodnioindyjskiej. Podstawowym indyjskim produktem importowanym i sprzedawanym przez Kompanię w Europie były tekstylia. Tekstylia indyjskie odegrały ważną rolę w narodzinach „nowożytnego materializmu” i rozwoju przemysłowego kapitalizmu, zmuszając brytyjskich przedsiębiorców do poszukiwania technologii, dzięki której mogli rywalizować z indyjskimi producentami (Cohn, 1996, s. 77).

Współczesna antropologia poświęca dużo uwagi badaniu hegemonicznej władzy towarów i marek, wskazując na aktywną rolę lokalnych konsumentów w udomawianiu Coca Coli czy McDonaldsa. Badania historyków w większym stopniu koncentrują się na transferze egzotycznej żywności i napojów z Nowego Świata do Starego. Jak wyjaśnić przemiany smaku i stylu życia, poczynając od początkowego odrzucenia wielu produktów w XVII w. do ich powszechnego przyjęcia w następnych wiekach? Hiszpańscy misjonarze przyswoili sobie nowe smaki poprzez zainteresowanie praktykami żywieniowymi Indian. Przykładem może być internalizowanie elementów indogenicznej estetyki i zwyczaju picia czekolady, który przenieśli do Starego Świata. Uznanie, że smak może stanowić rodzaj autonomicznej siły nie oznacza, że nie był on związany z politycznymi i społecznymi hierarchiami, które go legitymizowały, oceniały i kanalizowały. Zanim nowe formy zwyczajów społecznych (picie czekolady, herbaty, kawy) i codziennych rutyn (gorące napoje pite na 
śniadanie) wyewoluowały w oparciu o egzotyczne dobra musiały one zostać udomowione. Znaczące dla zmiany dietetycznego smaku było jego uprzednie osadzenie w systemie wiedzy. Botanicy, odkrywcy, badacze i doktorzy w XVII-wiecznej Holandii przyznawali smakowi centralną rolę w swoich badaniach. Obok abstrakcji i dyskursu uważali oni „smakową obiektywność" za klucz do zrozumienia świata. Prowadziło to do zainteresowania egzotycznymi dobrami i analizy ich dobroczynnych właściwości. Egzotyczne dobra takie jak gałka muszkatołowa, herbata, kakao, kawa itp., zyskały swój status w ramach tej naukowo-kulturowej hierarchii smaku i wiedzy (Trentmann, 2009, s. 208).

Niektóre indyjskie praktyki związane z ciałem zostały nie tylko przyjęte w Anglii, ale uznane wręcz za ,zachodnie”. Odnosiło się to w szczególności do regularnego kapania się i mycia głowy szamponem (ang. słowo shampoo pochodzi z języka Hindi). Praktyki te zaczęto później wiązać zarówno z chrześcijańską pobożnością, jak i, w związku z rolą mydła w końcu XIX w., ze wskaźnikiem poziomu cywilizacji społeczeństwa (Pomeranz, 2007, s. 77). Anne McClintock w studium na temat wzajemnych zależności między rasą, płcią kulturową i seksualnością w ramach „rywalizacji kolonialnej” ukazuje jak ideologiczne konstrukty powiązane z imperializmem znajdowały konkretny wyraz w codziennych, pozornie niewinnych formach, na przykład, właśnie rzeczach takich jak mydło do kąpieli. Odwołując się do sloganu reklamowego koncernu Unilever: mydło to cywilizacja, McClintock pokazuje, jak głęboko tkwi imperium w procesie budowania marki i promowania zwykłej kostki mydła. Czystość zostaje skojarzona nie tylko z pobożnością, ale także z wartościami, nawykami i instytucjami, które przyniosły wielkość imperium brytyjskiemu (McClintock, 2008). Nowy produkt łączy w sobie wszystkie konstytutywne cechy kapitalistycznego imperializmu. Został stworzony z olejków roślinnych wyprodukowanych na kolonialnych plantacjach, reklamowany jest za pomocą rasistowskich i patriarchalnych wyobrażeń fetyszyzujących czystość i udomowienie imperialnego porządku, sprzedawany jest zarówno mieszkańcom metropolitalnych slumsów, jak i niecywilizowanym tubylcom jako oznaka postępu. „Wszystkie wartości klasy średniej - monogamia (czyli wartość, jaką przedstawia «czysty» seks), kapitał przemysłowy (wartość «czystego» pieniądza), chrześcijaństwo («oczyszczająca krew baranka»), dominacja klasowa («czyści i brudasy») oraz imperialna misja cywilizacyjna («wymyć i ubrać dzikusa») - mogły zostać zawarte w najzwyklejszym produkcie gospodarstwa domowego" (McClontock, 1995). 
Przykłady te ukazująjak koncentrowanie się na analizach rzeczy poza wielkimi modelami modernizacji oraz świadome ograniczanie perspektywy, może oferować narzędzie o interesującym potencjale heurystycznym. Komparatywna obserwacja rzeczy jako „mediatorów” poprzez kultury chroni nas przed historiograficznym zachodnim ekscepcjonalizmem. Pozwala na konfrontowanie „różnorodności nowożytności” z „różnorodnością prenowożytności" i objaśnianie także prenowożytnych stosunków międzynarodowych jako procesu dezintegracji i integracji.

Bogactwo i luksus oraz bieda i ubóstwo objawiają się najczęściej za pośrednictwem rzeczy. Oba stany są skutkiem zróżnicowania ekonomicznego, które ma swoją wyraźną genezę w epoce brązu, ,[...] kiedy względny «egalitaryzm»ekonomiczny wcześniejszych społeczeństw został zburzony przez nowe techniki produkcji, które pozwoliły, by jeden człowiek z pługiem produkował znacznie więcej niż inny, czyniąc jednych zamożniejszymi, innych zaś uboższymi” (Goody, 2009, s. 274). Wiemy, że wszystkie społeczeństwa zmieniają się, choć w zależności od kontekstu $\mathrm{w}$ różnym tempie. Jedną z konsekwencji tych przekształceń są zmiany rzeczy uznawanych za wyróżniki bogactwa i luksusu. „Cukier, na przykład, był przed XVI w. luksusem, papier był nim wciąż jeszcze pod koniec XVII w., tak samo alkohol i pierwsze aperitify w czasach Katarzyny Medycejskiej, jak również łoża z łabędziego puchu i srebrne puchary rosyjskich bojarów przed Piotrem Wielkim" (Braudel, 1992, t. 1, s. 183).

W rozważaniach na temat pochodzenia określonych rzeczy (technologii) ważne jest wskazywanie społecznego kontekstu ich powstania i wykorzystania. Współczesny opór przed zastosowaniem pługa w niektórych regionach Afryki oznacza, że adaptacja nie polega jedynie na imporcie z zewnątrz określonych rzeczy (narzędzi, urządzeń, przedmiotów) i pozbyciu się przesądów na ich temat, ale na ustanowieniu nowego sposobu społecznej organizacji produkcji. Nie jest to zatem proces polegający na prostej zamianie o charakterze import-eksport. Wprowadzenie nowych rzeczy pociąga za sobą nie tylko zmiany związane z technicznymi skutkami ich wykorzystania, ale także często radykalne zmiany funkcjonowania danej społeczności w różnych aspektach życia społecznego (organizacja społeczna, podział pracy, stosunki własności, stosunki polityczne itp.).

Żadna cywilizacja nie może istnieć bez nieustannej wymiany doświadczeń, która jest wynikiem obecności sąsiadów. „Każda cywilizacja eksportuje i jednocześnie zapożycza dobra kultury. Nieważne, czy będzie to technika topienia wosku, busola, proch strzelniczy, sposób hartowania stali, system filozoficzny czy intelektualna moda [...]" (Braudel, 2006, 
s. 48). Fernand Braudel przedstawia listę rzeczy sporządzoną przez brazylijskiego socjologa, które jego rodzinna Brazylia przejęła od Europy w okresie od poł. XVIII do poł. XIX wieku. Na liście tej znajduje się: ciemne piwo z Hamburga, angielski dom drewniany, maszyna parowa, białe płócienne garnitury, sztuczne zęby, latarnie gazowe, tajne stowarzyszenia i system filozoficzny Augusta Comte'a (Braudel, 2006, s. 48). Braudel wskazuje na znaczenie struktur, które rozumie jako ,podstawy” każdej cywilizacji. Należą one zwykle do „czasu długiego” i mają „oryginalne cechy charakterystyczne" modelujące oblicze każdej cywilizacji. $\mathrm{Na}$ struktury te składają się wybory dokonane przed wiekami, zapożyczenia, imitacje i presje, ale także odmowy zapożyczeń od innych cywilizacji.

Stosunki międzynarodowe są konstytuowane poprzez nieustanne splatanie materialności i niematerialności. Podejmując próbę ukazania jak grupy społeczne posługują się rzeczami we wzajemnych relacjach możemy zademonstrować, jak poprzez różne praktyki odgrywają one kluczową rolę w budowaniu stosunków międzynarodowych. Można dążyć tym samym do zmiany znaczenia nadawanego materialności od „martwego świata” artefaktów rozumianych najczęściej jako „czynniki materialne” do ,żywego świata" rzeczy jako elementów budowy stosunków międzynarodowych. Ukazanie działania różnych rzeczy w różnych społeczeństwach odsłania ich wielowartościowość i płynność. Próby powiązania produkcji i konsumpcji różnych rzeczy pozwalają także na polityczne powiązanie producentów i konsumentów oraz zapobiegają ich depolityzacji, co często jest skutkiem konwencjonalnego podejścia do materialności w NSM.

Ukazanie w jaki sposób jedwab artykułował dramatyczne społeczno-ekonomiczne transformacje $\mathrm{w}$ Japonii w powiązaniu z procesami industralizacji w Stanach Zjednoczonych odsłania taki właśnie jego polityczny wymiar. Formowanie się japońsko-amerykańskiej sieci jedwabniczej współbrzmi z końcem systemu sprawowania władzy w Japonii przez dynastię Tokugawa i jej narodzinami jako nowożytnego państwa w systemie światowej ekonomii kapitalistycznej. Powstawanie tej sieci w latach 1854-1886 stanowiło jeden z kluczowych elementów włączania Japonii w światową ekonomię. O tranzycyjnym charakterze tego procesu świadczą szybko następujące zmiany w stosunkach między kapitałem i pracą oraz będące tego skutkiem formy kolektywnego protestu zarówno w Japonii (chłopskie rebelie w 1884 r., pierwsze znane strajki fabryczne w Japonii w latach 1885-1886), jak i w Stanach Zjednoczonych (strajki robotnicze w fabrykach jedwabiu w Paterson w latach 1885-1886). „Lokalne” wa- 
runki każdego z tych konfliktów były kształtowane przez okoliczności stanowiące konsekwencję podziału pracy dokonującego się w japońsko-amerykańskiej sieci jedwabniczej. Proces ten splatał formy produkcji i protestu obu uczestników tej sieci, których nie można traktować jako przebiegających według osobnych logik czy wzorców. Poprzez kupno surowca jedwabniczego i wpływ na produkcję jedwabiu w Japonii, fabryczne stosunki zmechanizowanej produkcji jedwabiu w Stanach Zjednoczonych łączyły się z historycznym środowiskiem chłopskiej hodowli jedwabnika i produkcji jedwabiu w Japonii, prowadząc do chłopskich rebelii i strajków robotnic. Podobnie, stosunki społeczne i warunki produkcji surowca jedwabniczego w Japonii poprzez jego eksport wpływały na warunki produkcji fabrycznej i konflikty społeczne w Paterson, centrum amerykańskiej produkcji jedwabiu. Stosunki produkcji jedwabiu w Japonii w coraz większym stopniu były kształtowane i podporządkowane przemysłowym stosunkom w Stanach Zjednoczonych warunkowanym przez rozwój produkcji fabrycznej i popyt na jedwab. Jako dostawcy surowca do wysoko zmechanizowanego i produktywnego amerykańskiego przemysłu jedwabniczego, japońscy producenci surowca jedwabniczego byli liczniejsi i mniej produktywni per capita. W rezultacie doświadczali oni między sobą większej presji konkurencji rynkowej niż oligopolistyczni przedsiębiorcy amerykańscy kupujący surowiec i sprzedający finalny produkt (Boles, 2002, s. 161). Analiza podziału pracy w tej japońsko-amerykańskiej sieci jedwabniczej pozwala na ukazanie powiązań między pozornie odległymi i niezwiązanymi wydarzeniami w Japonii i Stanach Zjednoczonych. Pozwala ona tym samym na ukazanie poprzez jedwab międzynarodowego wymiaru lokalnych wydarzeń i lokalnego wymiaru globalnej kapitalistycznej ekspansji i nierównej wymiany. Stany Zjednoczone wywierały na Japonię presję w celu jej angażowania się w handel z krajami zachodnimi na niekorzystnych zasadach. Oligarchia japońska wywierała nacisk na angażowanie się japońskich producentów przędzy jedwabniczej w światową ekonomię. Zarówno rządzący w okresie Tokugawa, jak i okresie Meiji popierali eksport surowca jedwabniczego, który dostarczał państwu zagranicznej waluty niezbędnej do stabilizacji jena i zakupu zagranicznej technologii, szczególnie militarnej (Gałganek, 2011, s. 7-33).

Mapa jest inną rzeczą ukazującą określoną wizualną reprezentację polityki międzynarodowej uzależnioną od społecznego kontekstu jej twórcy. Wizualizacja ta nie jest nigdy neutralna lub obiektywna. Mapy są ,przerysowywane” z powodów politycznych. Mogą one także wpływać na wyda- 
rzenia, a nie tylko je odzwierciedlać. Było to widoczne w strategiach stosowanych podczas II wojny światowej i zimnej wojny, kiedy określony typ projekcji był ściśle związany z podejmowanymi działaniami politycznymi. Mapy są aktantami lub aktorami. W maju 1999 r. amerykański samolot wojskowy wystrzelił rakietę, która uderzyła w ambasadę chińską w Belgradzie, zabijając cztery osoby spośród jej personelu. Rząd amerykański podjął próbę obwinienia za ten atak mapy zamiast wywiadu i wojskowych. Nawet jeśli atak był przypadkowy, mapa z pewnością nie wybrała celu. Stany Zjednoczone wyjaśniały, że celowano w oparciu o „stare mapy”, na których nie zaznaczono lokalizacji ambasady, chociaż ta zmieniła swoją lokalizację w 1996 r. i była nawet wizytowana przez amerykańskich dyplomatów (Klinghoffer, 2006, s. 12).

Objaśniając stosunki międzynarodowe związane z aktywnością ,morską" możemy zawęzić perspektywę, skupiając uwagę na statku/okręcie, który symbolizuje rolę całego świata morskiego w stosunkach międzynarodowych. Statek jest bowiem zarazem najbardziej starożytną i najbardziej nowoczesną przestrzenią. Posługując się pojęciem heterotopii Michel Foucault określa rzeczywiste miejsca, które są czymś w rodzaju kontrmiejsc, rodzajem utopii, w której wszystkie inne miejsca, jakie można znaleźć w ramach kultury są jednocześnie reprezentowane i kontestowane. Nawiązując do tego pojęcia można powiedzieć, że nowożytne narracje o morzu w pracach Melville'a, Marksa i Conrada stanowią jednocześnie apogeum i koniec statku jako heterotopii zachodniej cywilizacji. W narracjach tych przestrzeń statku symbolizuje paradygmat nowożytności tworzonej poprzez ścieranie się starego i nowego oraz nieustannie rosnące sprzeczności wynikające $\mathrm{z}$ tych zderzeń. $\mathrm{Z}$ jednej strony, morze jest jednym z najbardziej istotnych składników w badaniach nad kulturą kontaktu, z drugiej strony „każde wodowanie statku oznacza wprawienie w ruch kapitałów, które charakteryzuje przestrzenną «rewolucję» ery nowożytnej: okrążenie Ziemi poprzez włożone pieniądze i ich udany powrót na wyjściowe konto" (Sloterdijk, 2011, s. 106). Statek zawsze był czymś więcej niż tylko rzeczą. Stanowił on złożony kulturowy artefakt symbolizujący rozległe morskie tradycje i ich regionalne warianty. Statek w odróżnieniu od wielu innych przedmiotów łatwo przekraczający narodowe granice ma podobną człowiekowi aurę i uznany międzynarodowy status, a jego narodowość odgrywa istotną rolę w kulturowych wymianach (Tilburg, 2007, s. 38).

Zatem, to co zwykle rozumiemy przez materialną naturę rzeczy nie powinno ograniczać się tylko do ich własności, ale także odkrywać je jako 
społeczne projekcje nakładane na materialny świat poprzez język i odzwierciedlające ich kulturowe znaczenie, symboliczność czy stosunki dominacji i podporządkowania. Poznanie tekstualności materialnego świata znajdujące wyraz w stosunku między wiedza, reprezentacją, dyskursem i władzą pozwala na zrozumienie społecznego znaczenia nadawanego materialnym przedmiotom. Własności materialnego świata mogą być szczególnie trwałe w odróżnieniu od tekstualnych konstrukcji na jego temat, które mogą zmieniać się w czasie i przestrzeni (np. kontrhegemoniczny dyskurs związany z „krwawymi diamentami”). Ponadto, jak postuluja zwolennicy mikrohistorii i rozmaitych form ,gęstego opisu” (thick description) jednym z najbardziej znaczących sposobów badania świata społecznego jest odnajdywanie „uniwersalności w małych rzeczach” (Levi, 1991, rozdz. V). Jak wskazuje B. Latour, etnologowie, antropologowie, badacze folkloru, ekonomiści, inżynierowie, konsumenci i użytkownicy nigdy nie widzą rzeczy, lecz tylko plany, działania, zachowania, ustalenia, heurystyki, umiejętności, zbiory praktyk, z których znaczna część wydaje się nietrwała, a inne mają charakter przejściowy. W rezultacie nigdy nie można powiedzieć, które z nich - stal czy pamięć, rzeczy czy słowa, kamienie czy prawa - gwarantują dłuższe trwanie (Latour, 2000, s. 10).

$* * *$

W ramach szeroko rozumianej historii świata (world history) za szczególnie użyteczną w wyjaśnianiu stosunków międzynarodowych można uznać uprawianą przede wszystkim przez współczesnych historyków transnarodową historię (transnational history) oraz to co określają oni jako poziom „rzeczywistych badań”. Transnarodowa historia postuluje koncentrowanie się na badaniu wszelkiego typu przepływów poprzez granice państw narodowych. Badaniom tym towarzyszy założenie, że procesy historyczne nie mają swoich źródeł wyłącznie w państwach narodowych, ale są konstruowane w ruchu między miejscami i regionami. Najprościej mówiąc transnarodowa historia zajmuje się badaniem ludzi, idei, rzeczy i praktyk, które przekroczyły granice narodowe (Curthoys, Lake, 2005, s. 5-6). Akira Iriye i Pierre-Yves Saunier redaktorzy Palgrave Dictionary of Transnational History (2009) definiują transnarodową historię jako perspektywę, która koncentruje się na ,powiązaniach i przepływach” oraz ludziach, ideach, produktach, procesach i wzorcach, które operują ponad, poprzez i między jednostkami politycznymi oraz między społeczeństwa- 
mi (Iriye, Saunier, 2009, s. XVIII). Micol Seigel podkreśla, że określenie transnarodowa historia ma pozwolić na odróżnienie tego pola badawczego od historii stosunków międzynarodowych (international history) koncentrującej się na badaniu interakcji między państwami narodowymi. Transnarodowa historia koncentruje się zatem na badaniu „obiektów”, które „przelewają się” przez narodowe granice. Równocześnie nie jest ona tożsama $\mathrm{z}$ historią świata (world history), ponieważ historycy świata muszą nieustannie dokonywać wyboru między transnarodowym i międzynarodowym podejściem (Seigel, 2005, s. 63).

Byłoby błędem uważać, że cała historia świata jako pole badawcze koncentruje się na „wszystko obejmujących” wizjach ludzkiej przeszłości. Jedynie niewielka część prac powstałych w jej ramach podejmuje problem budowy światowych narracji. Na poziomie „rzeczywistych badań" historia świata zajmuje się nowymi obszarami i problemami metodologicznymi, które są niezbędne do prowadzenia szczegółowych studiów. W takim rozumieniu badania nad ,białym i czarnym Atlantykiem”, jedwabiem, szalami kaszmirskimi, powiązaniami ekonomicznymi, handlem i rewolucją przemysłową mogą stanowić ilustrację kulturowych przepływów między różnymi częściami świata. Szczególnie z punktu widzenia NSM tego rodzaju badania wykraczające poza konwencjonalną jednostkę analizy, jaką jest państwo narodowe pozwalają ukazać światowe transformacje, powiązania, adaptacje i inne zróżnicowane i kompleksowe procesy. „Historia Atlantyku” koncentruje się na oceanie, a jej jednostkami analizy stają się szlaki handlowe, rynki, sieci komunikacyjne i statki wiążące Afrykę, Europę, Ameryki i Karaiby w system.

Ponieważ badania tego rodzaju wymagają koncentrowania się na rozmaitych problemach w różnych czasach i przestrzeniach, w sposób nieunikniony historia świata jako dyscyplina charakteryzuje się metodologiczną różnorodnością. Wśród spektrum różnych podejść dostrzec można jednak dominujący trend polegający na dążeniu do kierowania się w badaniach transkulturowością. Świadczą o tym próby znajdujące swój wyraz w stworzeniu wielu nazw i neologizmów określających istotę tego postępowania: od „historii świata”, „historii globalnej”, „historii uniwersalnej”, „wielkiej historii” po „historię ekumeniczną”, ,powiązane historie” (connected histories), „splecione historie” (entangled histories) czy „,krzyżującą się historię" (l'histoire croisée) (Sachsenmaier, 2007, s. 469). Dodatkowym czynnikiem prowadzącym do pluralizacji tego pola badawczego jest ,nowy typ historyków" podejmujących tego rodzaju badania. Należą do nich zarówno historycy ekonomiczni, przedstawiciele socjologii historycznej, ba- 
dacze określonych regionów, badacze aktywności morskiej czy historycy nomadyzmu. Mamy nadzieję, że w coraz większej liczbie będą znajdować się wśród nich również badacze stosunków międzynarodowych, których nie satysfakcjonuje dominujące dotąd w NSM podejście koncentrujące się na państwie narodowym czy to $\mathrm{w}$ formie historii dyplomacji, czy historii politycznej. Ponadto, łatwo zauważyć, że w istocie wszystko o czym mówiliśmy do tej pory można uznać za aspekt „międzynarodowości”, a więc podstawowy przedmiot zainteresowania NSM.

Przyjęcie tego rodzaju ,transnarodowego nastawienia” i prowadzenie „rzeczywistych badań” pozwala uniknąć metodologicznego nacjonalizmu oraz pokazać, że możliwe jest objaśnianie stosunków międzynarodowych bez koncentrowania się na państwach. Metodologiczny nacjonalizm stał się przedmiotem namysłu i krytyki w wielu dyscyplinach nauk społecznych. Antropolodzy zaproponowali w ostatnich latach „studia transnarodowe" jako sposób wyjścia poza metodologiczny nacjonalizm łączący społeczeństwo z państwem narodowym. Państwa i ich instytucje są postrzegane jako znaczący, ale nie jedyni uczestnicy kształtujący społeczne, kulturowe, ekonomiczne i polityczne powiązania między ludźmi (Schiller, 2005, s. 440). Bardziej radykalna krytyka metodologicznego nacjonalizmu formułuje wręcz potrzebę równoczesnej dekonstrukcji nacjonalizmu, państwa narodowego, narodowych kultur i narodowych historii jako sposobu uniknięcia esencjalizacji stosunków transnarodowych, hybrydowych jednostek kulturowych, nienarodowych historii i sieciowych powiązań (Amelina, Faist, Schiller, Nergiz, 2012, s. 7).

Uważamy, że proponowana za ANT ontologia rzeczy jako pełnoprawnych aktorów stosunków międzynarodowych oferuje sposób wyzwolenia się z ograniczeń metodologicznego nacjonalizmu. Sądzimy, że metodologiczny nacjonalizm w NSM rozumiany jako „szczególna przychylność wobec państwa narodowego" jest empirycznie nieuzasadniony i konceptualnie dysfunkcjonalny.

ANT zmusza nas do uznania, że rzeczy, o których mówimy w NSM (broń, waluty, komputery, rakiety, ropa naftowa), a także te, którym zwykle nie poświęcamy szczególnej uwagi (nakrycia głowy, podarunki dyplomatyczne, kable podmorskie, jedwab, szale kaszmirskie, mydło) stanowią inherentną część sieci stosunków i praktyk, które tworzą nasz przedmiot poznania. Rzeczy takie jak głowice nuklearne powoduja, że politycy i dyplomaci robią „,rzeczy”, których z pewnością by nie robili, a które w znaczący sposób wpływają na stosunki międzynarodowe (Nexon, Pouliot, 2013, s. 343). 
Wreszcie, zainteresowanie badaczy stosunków międzynarodowych ANT odzwierciedla rosnące rozczarowanie „kulturowym redukcjonizmem" dominującym w teoriach stosunków międzynarodowych opartych na fundacyjnych rozstrzygnięciach filozofii społecznego konstruktywizmu. Debaty dotyczące konstruktywizmu jako propozycji teoretycznej w NSM explicité przeciwstawiają go „materializmowi”. Wskazywanie na szczególną rolę ,idei” w wyjaśnianiu międzynarodowej przyczynowości stanowi poparcie dla konstruktywizmu, zaś opowiadanie się za przyczynowym znaczeniem sił „materialnych” jest traktowane jako wsparcie dla niekonstruktywistycznych podejść, takich jak realizm i liberalizm (Nexon, Pouliot, 2013, s. 343). ANT oferuje możliwość porzucenia tego patologicznego dualizmu.

Teksty Bartosza Hordeckiego, Magdaleny Szkudlarek i Magdaleny Lorenc składają się na zbiór ilustrujący próbę wykorzystania ANT do rozumienia stosunków międzynarodowych.

Bartosz Hordecki w tekście pt. „Międzynarodowe życie rzeczy” w świetle „międzynarodowego życia osób” subtelnie rekonstruuje historię sposobów myślenia o strukturze „rzeczywistości” i dociera poprzez historię sporu o podmiotowość-przedmiotowość jednostki i państwa do fundamentu myślenia europejskiego. W jego rozważaniach dla badacza stosunków międzynarodowych szczególnie interesujące są tezy o paralelności myślenia Kartezjusza i Richelieu, teza o matematyzacji porządku międzynarodowego, rozważania o racji stanu, a także teza o zmodernizowanym świecie i człowieku, którzy stają się coraz szybciej rzeczami. Tekst dostarcza uzasadnienia dla kategorii ,podmiot” i ,przedmiot” (,rzecz” i „osoba”) jako najbardziej rozpowszechnionej formy myślenia w świecie zachodnim.

W tekście pt. Kapelusz kontra fez - o roli nakryć głowy w europeizacji Turcji Magdalena Szkudlarek analizuje proces budowy i europeizacji Turcji, badając figuracje nadawane fezowi, kapeluszowi i chuście. Nakrycia głowy zostały wykorzystane tam jako narzędzia modernizacji imperium. Autorka analizuje skomplikowane i fascynujące procesy, o niekiedy tragicznych, a czasami komediowych skutkach, w których fez rozumiany jako kwintesencja europejskości w imperium osmańskim, w pierwszych latach istnienia republiki zostaje zdegradowany do wstydliwej pozostałości po imperium i zastąpiony kapeluszem. Fezowi, kapeluszowi i chuście nadaje się waloru sprawczości. I chociaż, według Autorki, trudno twierdzić, że bez kapelusza nie byłoby modernizacji Turcji, a pozostawienie fezu uniemożliwiłoby ten proces, to każde z nakryć głowy stało się akantem procesu modernizacji i europeizacji Turcji. 
Tekst Magdaleny Lorenc pt. Do ut des, czyli rzecz o darze w dyplomacji. Przypadek siodta z daru sultana Mustafy II dla posła Stanisława Małachowskiego z 1699 roku jest próbą odpowiedzi na pytania o przyczyny i skutki stosowania normy ceremonialnej polegającej na wymianie darów na przykładzie polsko-tureckich stosunków dyplomatycznych w XVII wieku. Ponieważ wymianą darów rządziła zasada wzajemności, rzecz posiadająca sprawczość jako dar wywoływała określone skutki dyplomatyczne. Akantem stanowiącym przyczynek do refleksji nad praktyką darowania rzeczy w dyplomacji stanowi siodło z daru sułtana tureckiego Mustafy II dla Stanisława Małachowskiego, posła polskiego na rozmowy pokojowe w Karłowicach w latach 1698-1699. Autorka analizuje zachodni oraz wschodni, osadzony w tradycji dworu bizantyjskiego, ceremoniał dyplomatyczny. Ukazuje, analizując relacje z negocjacji, niewspółmierność występującą w nich między informacjami o merytorycznej stronie misji a ustępami dotyczącymi wymiany prezentów. Prowadzi to do wniosku o bliższości obyczajów dyplomatycznych dworów polskich królów ceremoniałowi wschodniemu. W tekście zawarta jest świetna analiza relacji między sprawczością daru-siodła i kontekstem jego darowania, który stanowiły negocjacje pokojowe w Karłowicach oraz stosunek polskiej szlachty do przedmiotów tureckiego pochodzenia. I chociaż sam dar-siodło nie spowodował podpisania układu karłowickiego, stanowił jednak rodzaj transakcji, której zawarcie nabrało charakteru międzynarodowego. Na przykładzie siodła Magdalena Lorenc ukazuje powiązanie czynników ludzkich i pozaludzkich oraz ich historyczną zmienność i zasadność odrzucenia esencjalistycznego traktowania rzeczy. Najważniejsze są relacje między uczestnikami aktu darowania.

\section{Bibliografia}

Amelina A., Faist T., Schiller N. G., Nergiz D. D. (2012), Methodological Predicaments of Cross-Border Studies, w: Beyond Methodological Nationalism. Research Methodologies for Cross-Border Studies, red. A. Amelina, T. Faist, N. G. Schiller, D. D. Nergiz, Routledge, New York.

Batchelor R. (2006), On the Movement of Porcelains: Rethinking the Birth of the Consumer Society as Interactions of Exchange Networks, China and Britain, 1600-1750, w: Consuming Cultures, Global Perspectives, red. J. Brewer, F. Trentmann, Oxford, Berg. 
Bauman Z., Kubicki R., Zeidler-Janiszewska A. (2009), Życie w kontekstach. Rozmowy o tym, co za nami i o tym, co przed nami, Wydawnictwo Akademickie i Profesjonalne, Warszawa.

Boles E. E. (2002), Critiques of World-Systems Analysis and Alternatives: Unequal Exchange and Three Forms of Class Struggle in the Japan-US Silk Network, 1880-1890, ,Journal of World-Systems Research”, vol. VIII, nr 2.

Braudel F. (1992), Kultura materialna, gospodarka i kapitalizm XV-XVIII wiek. Struktury codzienności, t. 1, PIW, Warszawa.

Braudel F. (2006), Gramatyka cywilizacji, Oficyna Naukowa, Warszawa.

Bueger Ch. (2013), Actor-Network Theory, Methodology, and International Organization, „International Political Sociology”, vol. 7, issue 3.

Cohn B. S. (1996), Colonialism and its Forms. The British in India, Princeton University Press, Princeton.

Curthoys A., Lake M. (2005), Introduction, w: Connected Worlds. History in Transnational Perspective, red. A. Curthoys, M. Lake, Australian National University, Canberra.

Dant T. (1999), Material Culture in the Social World: Values, Activities, Lifestyles, Open University Press, Buckingham.

Edwards E., Gosden Ch., Philips R. B. (2006), Sensible Objects. Colonialism, Museums and Material Culture, Berg, Oxford (New York).

Gałganek A. (2011), Życie międzynarodowe rzeczy. Przedmioty luksusu i codziennego użytku w społecznej historii stosunków międzynarodowych, ,Przegląd Politologiczny", vol. XVI, nr 3.

Goody J. (2009), Kradzież historii, Wydawnictwo Naukowe PWN, Warszawa.

Iriye A., Saunier P-Y. (2009), The Palgrave Dictionary of transnational history from the mid $-19^{\text {th }}$ century to the present day, Palgrave Macmillian, Houndmills.

Klinghoffer A. J. (2006), The Power of Projections: How Maps Reflect Global Politics and History, Praeger, Westport.

Kopytoff I. (1986), The Cultural Biography of Things: Commoditization as Process, w: The Social Life of Things: Commodities in Cultural Perspective, red. A. Appaduari, Cambridge University Press, Cambridge.

Latour B. (2000), The Berlin Key or How to do Words with Things, w: Matter, Materiality and Modern Culture, red. P. M. Graves-Brown, Routledge, London.

Latour B. (2007), A plea for earthly sciences. Keynote lecture for the annual meeting of the British Sociological Association, London.

Latour B. (2010a), Splatajac na nowo to, co społeczne. Wprowadzenie do teorii aktora-sieci, Universitas, Kraków.

Latour B. (2010b), Przedmioty także posiadaja sprawczość, w: Teoria wiedzy o przeszłości na tle współczesnej humanistyki, red. E. Domańska, Wydawnictwo Poznańskie, Poznań. 
Levi G. (1991), On Microhistory, w: New Perspective on Historical Writing, red. P. Burke, Polity Press, Cambrigde.

McClintock A. (1995), Imperial Leather: Race, Gender and Sexuality in the Colonial Contest, London-New York [cytuję tłum. Jacka Dobrowolskiego w: A. Colás (2008), Imperium, Wydawnictwo Sic!, Warszawa].

Nexon D. H., Pouliot V. (2013), ,, Things of Networks ”: Situating ANT in International Relations, „International Political Sociology”, vol. 7, issue 3.

Novack G. (1972), Uneven and Combined Development in World History, w: G. Novack, Understanding History, Pathfinder Press, New York.

Olsen B. (2010), Kultura materialna po tekście, w: Teoria wiedzy o przeszłości na tle współczesnej humanistyki, red. E. Domańska, Wydawnictwo Poznańskie, Poznań.

Pomeranz K. (2007), Social History and World History: From Daily Life to Patterns of Change, „Journal of World History”, vol. 18, nr 1.

Sachsenmaier D. (2007), World History as Ecumenical History?, „Journal of World History", vol. 18, nr 4.

Schiller D. (2011), Geopolitical-economic conflict and network infrastructures, „Chinese Journal of Communication", vol. 4, nr 1.

Schiller N. G. (2005), Transnational social fields and imperialism: Bringing a theory of power to Transnational Studies, „Anthropological Theory”, vol. 5, nr 4.

Seigel M. (2005), Beyond Compare: Comparative Method after the Transnational Turn, „Radical History Review”, nr 91.

Serres M. (1989), Detachment, Ohio University Press, Athens.

Serres M. (1995), Genesis, The University of Michigan Press, Ann Arbor.

Sloterdijk P. (2011), Kryształowy pałac. O filozoficznq teorię globalizacji, Wydawnictwo Krytyki Politycznej, Warszawa.

Taussig M. (1993), Mimesis and Alterity: A Particular History of the Senses, Routledge, New York.

Trentmann F. (2009), Crossing Divides. Consumption and globalization in history, „Journal of Consumer Culture”, vol. 9, nr 2.

Trubitt M. B. D. (2003), The Production and Exchange of Marine Shell Prestige Goods, „Journal of Archaeological Research”, vol. 11, nr 3.

Van Tilburg H. K. (2007), Vessels of Exchange. The Global Shipwright in the Pacific, w: Seascapes. Maritime Histories, Littoral Cultures, and Transoceanic Exchanges, red. J. H. Bentley, R. Bridenthal, K. Wigen, University of Hawai'i Press, Honolulu. 


\title{
International life of things. Introduction
}

\begin{abstract}
Summary
The main goal of this article is introduction to the Actor-Network Theory (ANT) to raise questions about its role in International Relations. While concepts of ANT are very promising we propose to treat ANT as a new theoretical model for international relations scholarship. ANT argues us to recognize that such things as currency, weapons, computers, ships, silk, and others objects are inherent part of international relations. The interest of ANT in International Relations reflects a growing dissatisfaction with the cultural reductionism (constructivism) and methodological nationalism. ANT abandons the dichotomy between the idea and material and argue that such dualisms might prevent us from understanding of international relations. Rejecting this dualisms is to argue for ontological multiplicity of international relations. We initiating in polish International Relations what we hope will be example to bring ANT and International Relations into conversation.
\end{abstract}


